\title{
Correction to: Incidence of dyschromatopsy in glaucoma
}

\author{
Laura Bayer · Jens Funk • Marc Töteberg-Harms 1
}

Published online: 25 February 2020

(c) Springer Nature B.V. 2020

Correction to: Int Ophthalmol

https://doi.org/10.1007/s10792-019-01218-1

Publisher's Note Springer Nature remains neutral with regard to jurisdictional claims in published maps and institutional affiliations.

In the original publication, the family and given name of authors were swapped incorrectly in the author group. The correct author group is given in this correction. The original article has been corrected.

The original article can be found online at https://doi.org/10.1007/s10792-019-01218-1.

L. Bayer · J. Funk · M. Töteberg-Harms $(\bowtie)$ Department of Ophthalmology, University Hospital Zurich, Frauenklinikstrasse 24, 8091 Zurich, Switzerland e-mail: marc.toeteberg@usz.ch 